\title{
Determination of The Curie Point Depth, Thermal Gradient and Heat Flow of Parts of Central And North-Eastern Nigeria Using Spectral Analysis Technique
}

\section{George Idena Odidi ( $\boldsymbol{\nabla}$ idenageorge@gmail.com )}

University of Abuja Faculty of Sciences https://orcid.org/0000-0002-7580-4834

\section{Abu Mallam}

Physics Department, Faculty of Science, University of Abuja, Nigeria, Abu.mallam@uniabuja.edu.ng Naeem Nasir

Physics Department, Faculty of Science, University of Abuja, Nigeria, nassnaeem@gmail.com

\section{Research}

Keywords: Aeromagnetic data, Curie point depth, Heat flow, geothermal gradient

Posted Date: September 3rd, 2020

DOI: https://doi.org/10.21203/rs.3.rs-67770/v1

License: (c) (1) This work is licensed under a Creative Commons Attribution 4.0 International License. Read Full License 
DETERMINATION OF THE CURIE POINT DEPTH, THERMAL GRADIENT AND HEAT FLOW OF PARTS OF CENTRAL AND NORTH-EASTERN NIGERIA USING SPECTRAL ANALYSIS TECHNIQUE

Odidi I.G.

Integrated Science Department, School of Secondary Science Education, Federal College of Education Zaria, kaduna State, Nigeria.

idennageorge@gmail.com

Professor Mallam A.

Physics Department, Faculty of Science, University of Abuja, Nigeria

Abu.mallam@uniabuja.edu.ng

Dr. Nasir N.

Physics Department, Faculty of Science, University of Abuja, Nigeria nassnaeem@gmail.com 


\begin{abstract}
Radially power spectrum was applied to the aeromagnetic data covering an area $36,300 \mathrm{~km}^{2}$ and bounded by latitudes $7.5^{\circ} \mathrm{N}$ and $11.5^{\circ} \mathrm{N}$ and longitudes $7.5^{\circ} \mathrm{E}$ and $10.5^{\circ} \mathrm{E}$., divided into 35 square blocks (with 50\% overlapping and approximately 64 by 64 data points) and each block analysed using the spectral centroid method to obtain depth to the top, centroid and bottom of magnetic sources. The result shows that the curie point depths, range from $17.711 \mathrm{~km}$ to $34.34 \mathrm{~km}$, with a mean value of $26.21 \mathrm{~km}$, geothermal gradient, range from 16.89 ${ }^{0} \mathrm{C} \mathrm{km}^{-1}$ to $32.75{ }^{0} \mathrm{C} \mathrm{km}^{-1}$, with a mean value of $22.83{ }^{0} \mathrm{C} \mathrm{km}^{-1}$ and heat flow, range from $42.22 \mathrm{mWm}^{-2}$ to $81.87 \mathrm{mWm}^{-2}$, with a mean value of $57.07 \mathrm{mWm}^{-2}$. These results correlate with the existing geothermal and geo-tectonic signatures of the area. Hence, the possibility of the existence of geothermal resources in the study area and its possible exploration is not far fetch.
\end{abstract}

Key Words: Aeromagnetic data, Curie point depth, Heat flow, geothermal gradient. 


\section{Introduction}

The Curie point depth is the theoretical surface where ferromagnetic minerals are converting to paramagnetic minerals and it is assumed to have a temperature of approximately $580{ }^{0} \mathrm{C}$, above which the former loses its magnetism and can be considered an indicator of the bottom of a magnetic crust. Hinze et al., 2013, in the Laboratory experiments they carried out, showed that ferromagnetic materials lose their magnetism above the Curie temperature (580 ${ }^{\circ} \mathrm{C}$ ) because the thermal energy is sufficient to maintain a random alignment of the magnetic moments of the iron minerals. Also, Manea and Manea, 2011 opined that, an estimate of the bottom of magnetized crust represents a direct indicator of the Curie isotherm, and variations in the thickness of the magnetized crust can be explained as variations in temperature. Magnetic minerals warmer than their Curie point depth temperatures are paramagnetic and are essentially nonmagnetic. The present study attempts to determine the depths to the top and bottom of the magnetized crust and to characterize the heat flow within the study area using Curie point depth (CPD) estimates from spectral analysis of aeromagnetic data. In this study, the spectral analysis technique will be utilized in order to estimate the CPD from aeromagnetic data over the study area bounded by latitudes $7.50^{\prime} \mathrm{N}$ to $11.50^{\prime} \mathrm{N}$ and longitudes 7.50'E to 10.50 'E located within the central and northeast Nigeria (Fig.1. and Fig. 2). The study area covered $36,300 \mathrm{~km}^{2}$ and it is made up of the cretaceous Benue trough, Precambrian basement Complex, Sedimentary Basins (Gongola and Yola Basins), Jurassic younger Granites, and tertiary - recent sediments of the central and north-eastern Nigeria (Carter et al., 1963; Ekwueme, 1987; Kogbe, 1989; Farnbauer and Tietz, 2000; Reyment, 1965; Adelana et al., 2008). Also, two prominent Hot Springs are located within the area, Wiki hot spring in Yankari, Bauchi state and Akiri hot spring in Awe, Nasarawa state (Fig.1.). These warm springs makes the study very significant as they are clear indication of surface manifestation of geothermal activities within the study area. The possibility of harnessing 
geothermal resources in the area for economic and other purposes are not far fetch. This cannot be over emphasised, as the current over dependence of Nigeria on fossil fuel (oil and natural gas) has constituted an obstacle to the development of geothermal energy resources in the country and technological advancement. Nur et al., 1999; Obaje, 2009; Eletta and Udensi 2012; Salako 2012; Abdulsalam et al., 2013; Ikumbur et al., 2013; Igwesi and Umego 2013; Bello et al., 2017; Mohammed et al., 2019; Abdullahi et al., 2019, have done several works in different parts of the world both on local and regional scale using the magnetic method to determine the Curie point depth. Results obtained from this study will be invaluable in the development and a better understanding of the thermal and crustal structure of the study for geothermal exploration and exploitation. 


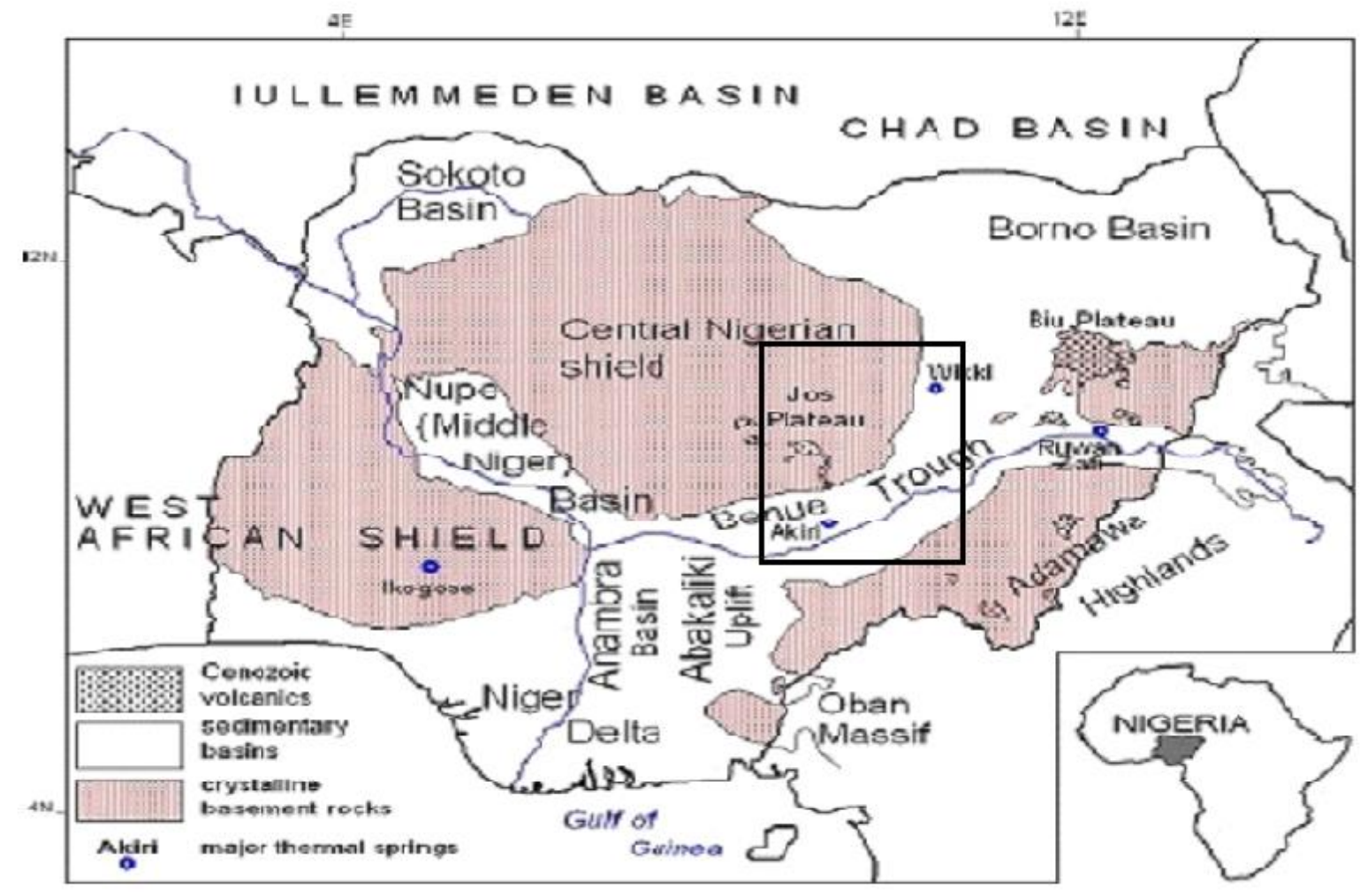

$\square$ Study Area

- Surface Geothermal manifestation - Hot springs.

Fig.1: Geological setting and location of areas with major geothermal manifestation (Hot springs) in Nigeria (After Kurowska and Schoeneich, 2010). 


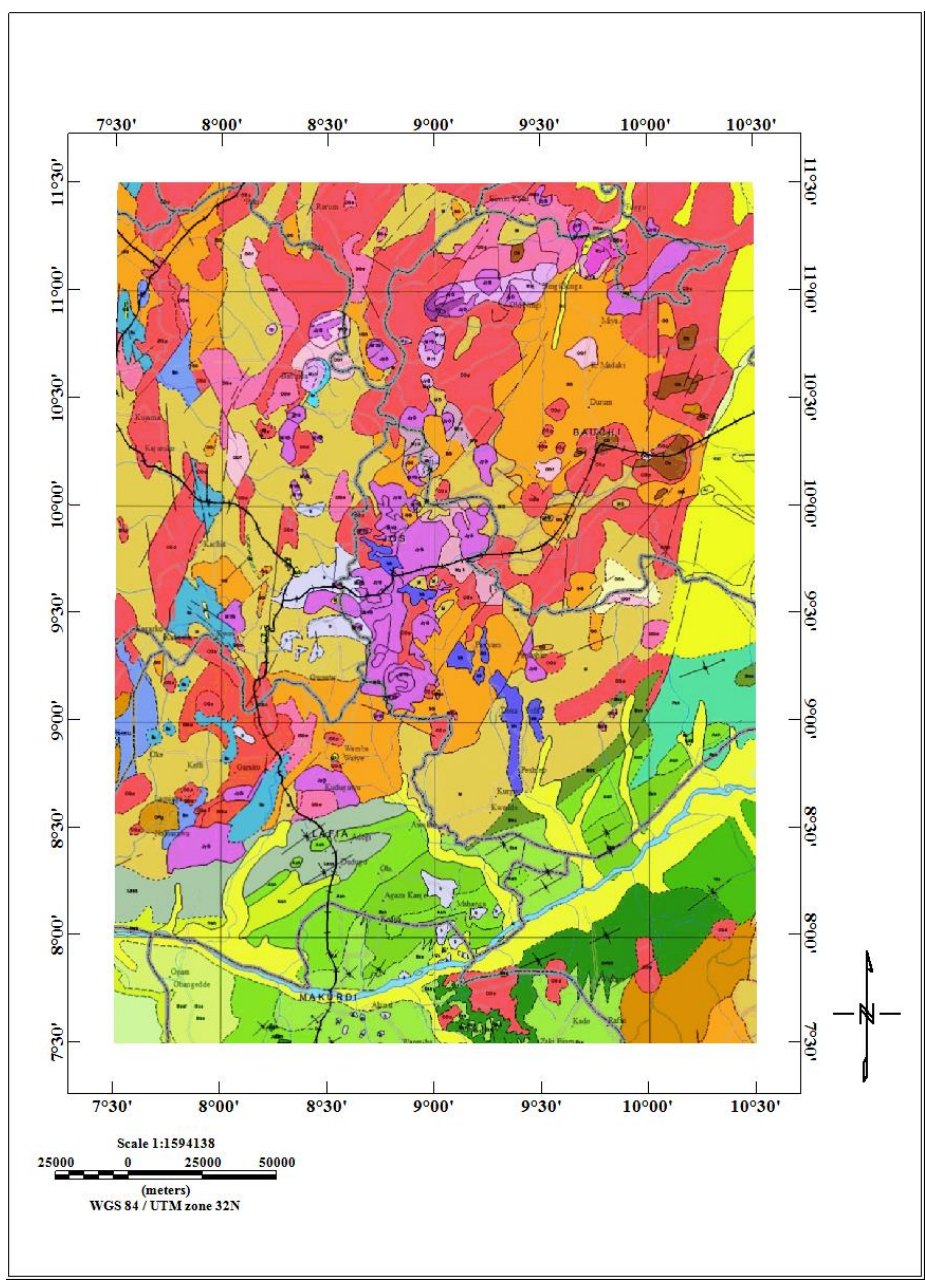

\section{EXPLANATION}

sop sund Cing wa Subeng

ot Sonts, Clys, nintoces ansinentotes,

Cri sent mater

to Eosat

Io biprin, Cloptene and that

vik Coyebyny sseds onsthels?

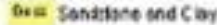

var swatidoce Lustitone Coat

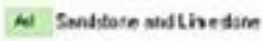

Mtr Consunatsme ons seste

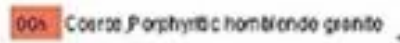

peell hosthrise oearese

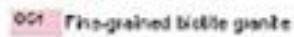

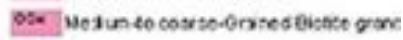

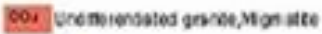

I9. Cratreakateros:

bah slot:o Hombionoe Qreise

bi lidise comet Oneist seriat

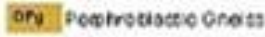

so Granie Gness

0. Ounte feldsentric grasilte and gnei

20 Banded Gniss f Eure Oneiss

Mol Mimacte ovosh onaso

45 Minwots Greis

M Minneise

Fig.2: Geological Map of the study area (adapted after NGSA, 2010) 


\section{MATERIALS AND METHODS}

The idea of using the magnetic method to determine the Curie point depth was based on the theory proposed by Bhattacharrya (1966) and developed by (Spector and Grant,1970; Blakely, 1988; Blakely, 1995; Tanaka et al., 1999) were they stated that geomagnetic anomalies collected from aeromagnetic data can be utilise to compute the curie point depth of an area. Bhattacharyya and Leu, 1975; Byerly and Stolt, 1977; Blakely and Hassanzadeh, 1981; Blakely, 1988; Smith and Braile, 1994; Tanaka et al., 1999; Chiozzi et al., 2005; Eppelbaum and Pilchin, 2006; Trifonova et al., 2009; Aboud et al., 2011, all used geomagnetic anomalies, which are retrieved from magnetic survey (Aeromagnetic data) to estimate the Curie point depth. The high resolution aeromagnetic dataset, which consist of sheet $102-107,124-129,145-150,166-171,187-192,208-213,229-234$ and $249-$ 254 utilized for this study was obtained as controlled maps of total magnetic intensity on a scale of 1:100000 compiled by the Nigerian Geological Survey Agency as a part of the nation-wide aeromagnetic survey between 2005 and 2010. The survey was flown in drape mode using real time global positioning system at a sensor mean terrain clearance of 80 $100 \mathrm{~m}$. Traverse and Tie line spacing were $500 \mathrm{~m}$ and $2000 \mathrm{~m}$ respectively in NW-SE and NESW directions and the data were recorded at a sampling interval of 100m (NGSA, 2010) and stored in grid form. The study area is covered by forty-eight aeromagnetic maps of total-field intensity in $1 / 2^{o}$ by $1 / 2^{o}$ sheets. The data were initially pre-processed by Fugro Airborne Survey and Consultant teams, pre-processing operation included micro levelling, removal of cultural effects as well as filtering for noise contents. Total magnetic field intensity maps of the area comprising of the sheets (Fig. 3) were plotted using Oasis Montaj software (version 8.4). The composite colour map (Fig. 3) effectively displayed both long wavelength and short wavelength features. Oasis Montaj software (version 8.4) grid maths was used to generate the residual magnetic field intensity map Fig.4. from the total magnetic field intensity grid. 


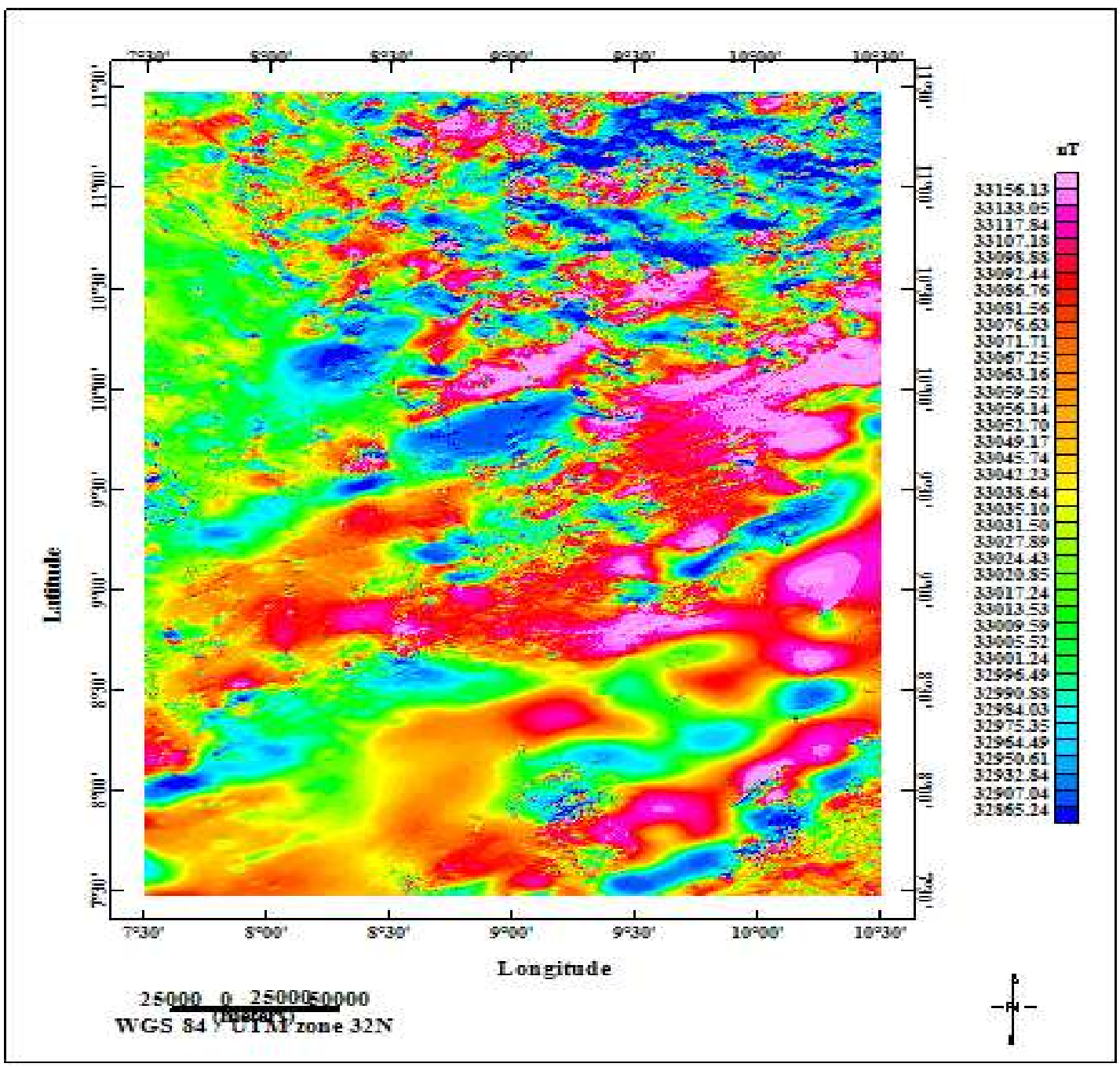

Fig.3: Total magnetic field intensity map of the study area. 


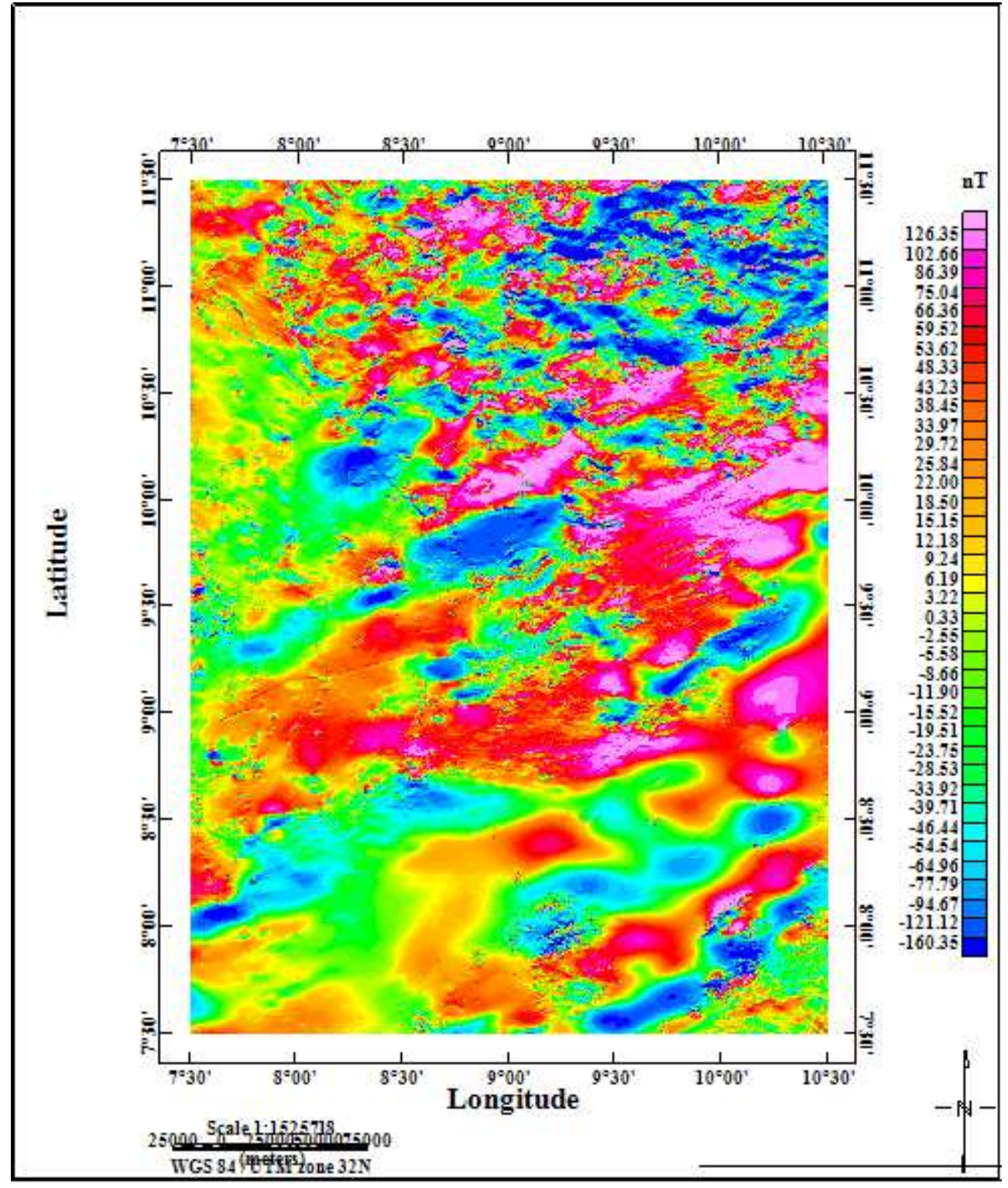

Fig.4: Residual magnetic field intensity map of the study area. 


\section{Curie point depth estimation}

The technique for computing the depth extent of magnetic sources, which deals with the examination of the patterns of the anomalies, and provide the relationship between the spectrum of the magnetic anomalies and the depth to magnetic sources, by transforming the spatial data into frequency domain proposed by Spector and Grant (1970), was adopted in this study and has been proven to be reliable in the calculation of average depth to magnetic crust. It stipulates that, from graphs of the logarithms of the spectral energies for the various blocks, one can estimate the depth to Centroid $\left(Z_{\mathrm{o}}\right)$ of the magnetic source from the slope of the longest wavelength part of the spectrum

$$
\ln \left\{\left[\phi_{\Delta T}(|k|)^{1 / 2}\right] /|k|\right\}=\ln D-|k| Z_{o}
$$

Where $\ln \left\{\left[\phi_{\Delta T}(|k|)^{1 / 2}\right] /|k|\right\}$ is the radially averaged power spectrum of the anomaly, / $\mathrm{k} /$ is the wave number, and $\mathrm{D}$ is a constant and estimate the depth to the top boundary $\left(\mathrm{Z}_{\mathrm{t}}\right)$ of that distribution from the slope of the second longest wavelength spectral segment (Okubo et al, 1985),

$$
\ln \left[\phi_{\Delta T}(|k|)^{1 / 2}\right]=\ln B-|k| Z_{t}
$$

Where $\ln \left[\phi_{\Delta T}(|k|)^{1 / 2}\right]$ is the radially averaged power spectrum of the anomaly, $/ \mathrm{k} /$ is the wave number, and B is the sum of constants independent of $/ \mathrm{k} /$. According to (Okubo et al., 1985; Tanaka et al., 1999), the basal depth $\left(Z_{b}\right)$ of the magnetic source can be calculated from the equation,

$$
Z_{b}=2 Z_{o}-Z_{t}
$$

The obtained basal depth $\left(\mathrm{Z}_{\mathrm{b}}\right)$ of magnetic sources in the study area is assumed to be the Curie point depth (Bhattacharyya and Leu 1975 and Okubo et al., 1985). 


\section{Estimation of Heat flow and thermal gradient}

The expression for the calculation of heat flow and thermal gradient values as derived from Fourier's law (Fourier 1955) is given by;

$$
\mathrm{q}=\lambda \frac{d T}{d Z}
$$

Where $\mathrm{q}$ is the heat flow and $\lambda$ is the coefficient of thermal conductivity. In this equation, it is assumed that the direction of the temperature variation is vertical and the temperature

gradient $\frac{d T}{d Z}$ is constant. According to Tanaka, et al, (1999), the Curie temperature $(\theta)$ can be obtained from the Curie point depth $\left(\mathrm{Z}_{\mathrm{b}}\right)$ and the thermal gradient $\frac{d T}{d z}$ using the following equation;

$$
\theta=\left\{\frac{\mathrm{dT}}{\mathrm{dZ}}\right\} Z_{\mathrm{b}}
$$

Provided that there are no heat sources or heat sinks between the earth surface and the Curie point depth, the surface temperature is $0^{\circ} \mathrm{C}$ and $\frac{d T}{d T}$ is constant. The Curie temperature depends on magnetic mineralogy. The commonest magnetic substance in the earth is magnetite $\left(\mathrm{Fe}_{2} \mathrm{O}_{4}\right)$, with Curie temperature approximately $580^{\circ} \mathrm{C}$ (Nwankwo et al., 2011). From equation (4) and equation (5), the heat flow (q) can be express as;

$$
\mathrm{q}=\lambda\left\{\frac{\theta}{\mathrm{Zb}}\right\}
$$

In this equation, the Curie point depth is inversely proportional to the heat flow (Tanaka et al. 1999; Stampolidis, et al., 2005). In this research, the Curie point temperature of $580{ }^{\circ} \mathrm{C}$ and thermal conductivity of $2.5 \mathrm{Wm}^{-1}{ }^{\circ} \mathrm{C}^{-1}$ as average for igneous rocks was used as standard (Nwankwo et al., 2011) in the study area. In order to compute the thermal gradient and heat flow, Equation (6) was utilised. See Table 1 below. 
Radially power spectrum was applied to the residual magnetic field intensity grid map of the study area divided into 35 square blocks (each block covers a square area of 110 by $110 \mathrm{~km}$, which approximately represent a square grid of 64 by 64 data points, $\mathbf{c 1}-\mathbf{c 2}$, (Fig.5) with $50 \%$ overlapping) and each block analysed using the spectral centroid method to obtain depth to the top, centroid and bottom of magnetic sources. The analysis was carried out using computer software (Oasis Montaj (version 8.4), Grapher 8, Microsoft Office and Surfer 15). The depth values were subsequently used to evaluate the Curie-point depth (CPD), geothermal gradient and near-surface heat flow in the study area. 


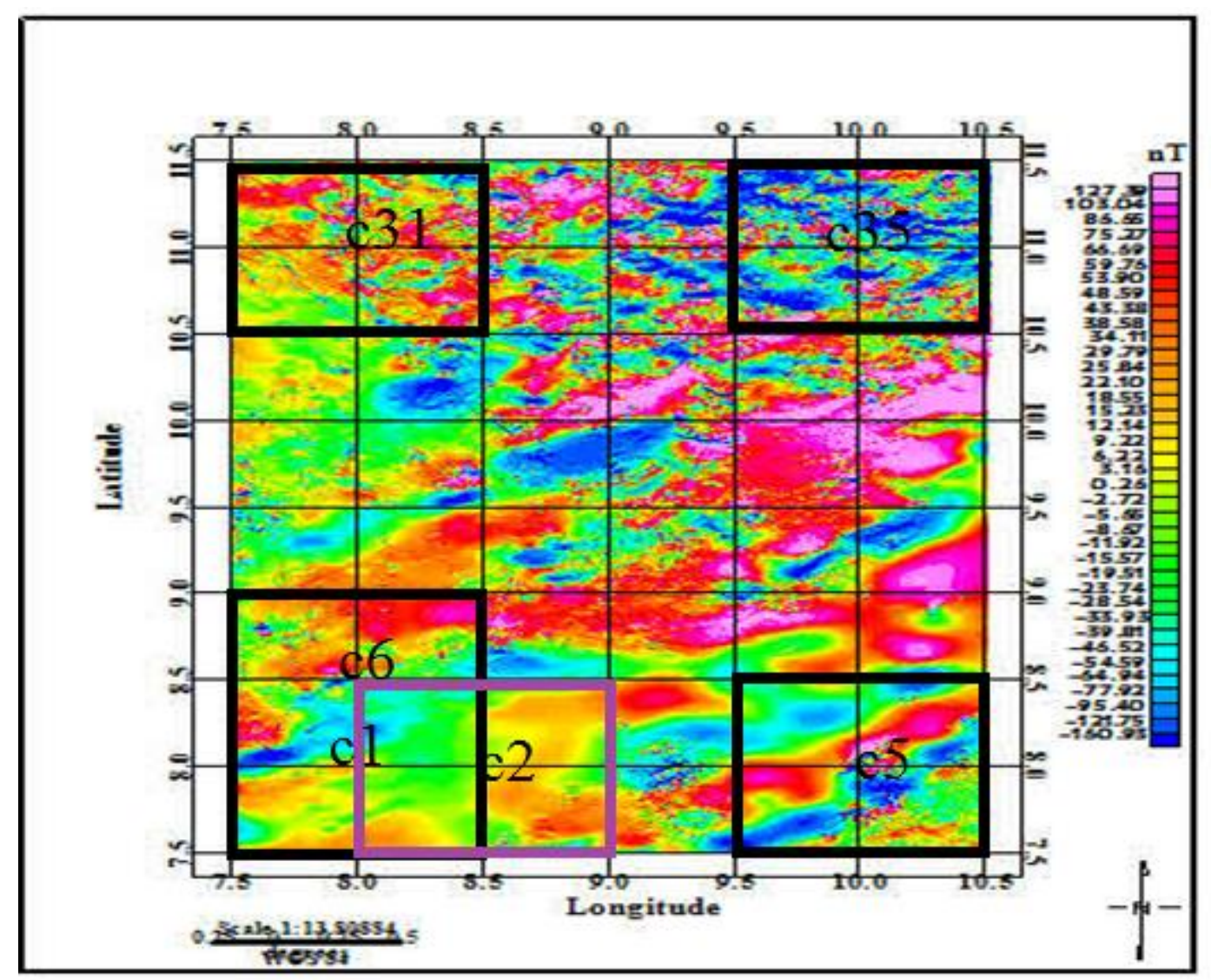

Fig.5: Residual magnetic field intensity divided into thirty-five square windows (110km by $110 \mathrm{~km}$ each) from $\mathrm{c} 1$ to $\mathrm{c} 35$ at $50 \%$ overlapping.

\section{Results and Discussion}

Radially power spectrum was applied to the aeromagnetic data of the study area divided into 35 square blocks (with 50\% overlapping). Fig.6 shows the sample graphs of the logarithms of the spectral energies for plots of blocks c33 and c34.The determined values of the basal depth or depth to the magnetic source $\mathrm{Z}_{\mathrm{b}}$, for blocks c33 and c34 using their determined $\mathrm{Z}_{\mathrm{o}}$ and $\mathrm{Z}_{\mathrm{t}}$ values in equation (3) are $11 \mathrm{~km}$ and $13 \mathrm{~km}$ respectively. The results of the determined values of $\mathrm{Z}_{\mathrm{o}}, \mathrm{Z}_{\mathrm{t}}$ and $\mathrm{Z}_{\mathrm{b}}$ for the thirty-five blocks are shown in table 1.The curie point depths, range from $17.711 \mathrm{~km}$ to $34.34 \mathrm{~km}$, with a mean value of $26.21 \mathrm{~km}$, geothermal gradient, range from 
$16.89{ }^{0} \mathrm{C} \mathrm{km}^{-1}$ to $32.75{ }^{0} \mathrm{C} \mathrm{km}^{-1}$, with a mean value of $22.83{ }^{0} \mathrm{C} \mathrm{km}^{-1}$ and heat flow, range from $42.22 \mathrm{mWm}^{-2}$ to $81.87 \mathrm{mWm}^{-2}$, with a mean value of $57.07 \mathrm{mWm}^{-2}$. The curie point depth of the study area compare favourably with what was recorded over Sarti and environs of North-Eastern Nigeria (range from 24 to 28km, Kasidi and Nur (2012)), Jalingo and Environs, North-Eastern part of Nigeria (range from 26 to $28 \mathrm{~km}$, Kasidi and Nur (2013)), the eastern Chad basin, Nigeria ((Mafa - Bama and Maiduguri - Gwoza areas) (range from 21 to $32 \mathrm{~km}$, Anakwuba, et al., (2016))), the entire Bida Basin in north-central Nigeria (range from 16 to $30 \mathrm{~km}$, Nwankwo and Sunday (2017)), part of the upper Benue trough corresponding to Kaltungo, Guyok, Lau and Dong areas, north eastern Nigeria (range from 12 to 34 km, Mohammed et al., (2019)) and the Upper Benue Trough (range from 24 to $33 \mathrm{~km}$, Nur et al., (1999)). 

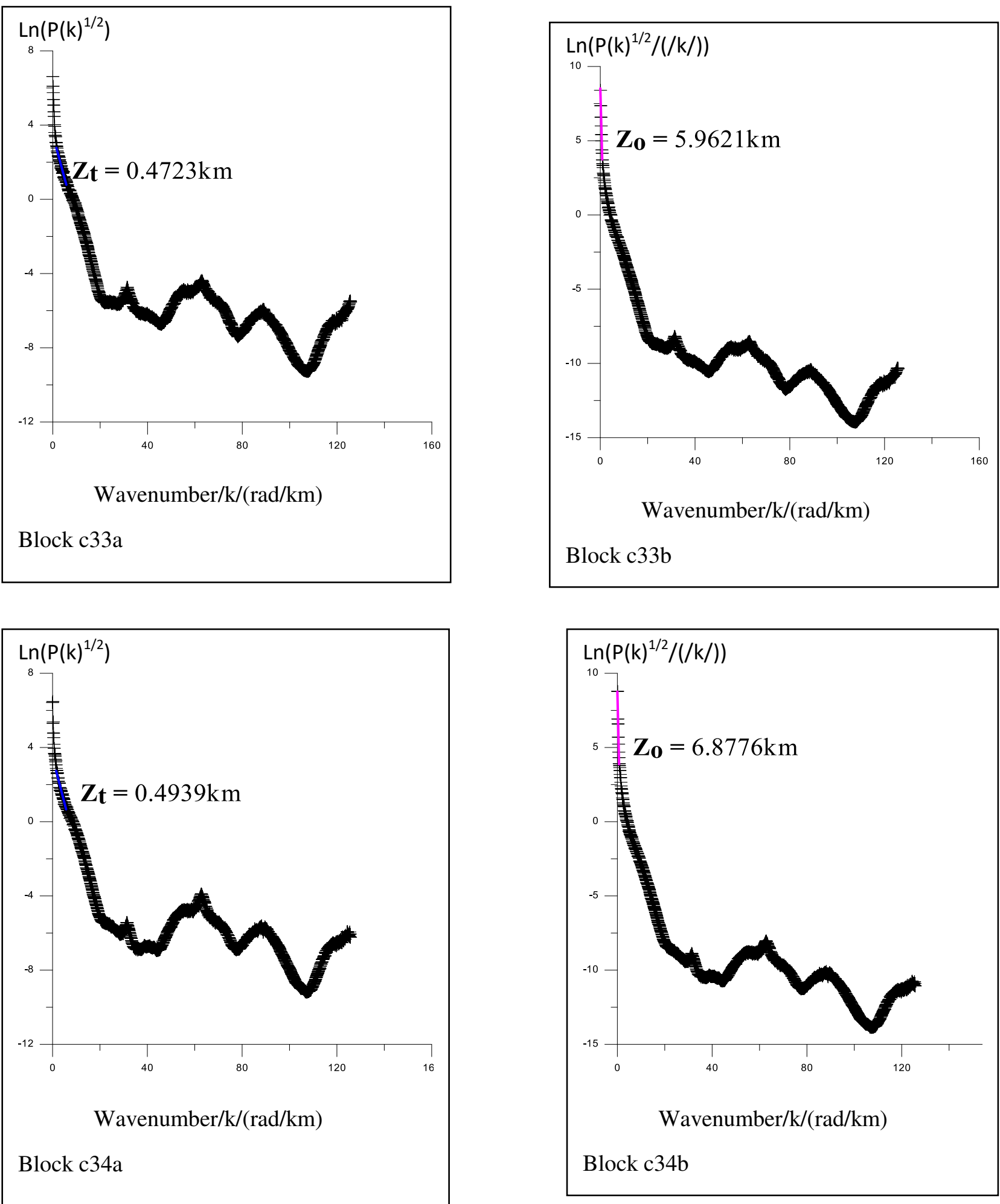

Fig.6: Graphs of the logarithms of the spectral energies for blocks c33, and c34, showing the determined values of $\mathrm{Z}_{\mathrm{o}}$ and $\mathrm{Z}_{\mathrm{t}}$ using Grapher 8 software and the calculated Curie point depths are $11 \mathrm{~km}$ and $13 \mathrm{~km}$ respectively. 
Table.1: Calculated Average Curie point depth, Geothermal gradient and Heat flow from spectral analysis

\begin{tabular}{|c|c|c|c|c|c|}
\hline Blocks & $\begin{array}{l}\text { Depth to } \\
\text { Centroid } \\
\left(\mathrm{Z}_{\mathbf{0}}\right)\end{array}$ & $\begin{array}{l}\text { Depth to top } \\
\text { boundary } \\
\left(Z_{t}\right)(\mathbf{k m})\end{array}$ & $\begin{array}{c}\text { Curie Depth }\left(Z_{\mathbf{b}}\right) \\
(\mathbf{K m})\end{array}$ & $\begin{array}{l}\text { Geothermal gradient }\left(\frac{d T}{d z}\right) \\
\left({ }^{\circ} \mathbf{C} / \mathbf{k m}\right)\end{array}$ & $\begin{array}{l}\text { Heat Flow (q) } \\
\left(\mathbf{m W m}^{-2}\right)\end{array}$ \\
\hline c1 & 15.311 & 0.775 & 30 & 19 & 48 \\
\hline c2 & 15.244 & 0.428 & 30 & 19 & 48 \\
\hline c3 & 15.152 & 0.270 & 30 & 19 & 48 \\
\hline $\mathrm{c} 4$ & 14.622 & 0.269 & 29 & 20 & 50 \\
\hline c5 & 9.790 & 0.322 & 19 & 30 & 75 \\
\hline c6 & 14.527 & 0.498 & 28 & 20 & 51 \\
\hline c7 & 13.744 & 0.432 & 27 & 21 & 54 \\
\hline $\mathrm{c} 8$ & 14.366 & 0.393 & 28 & 20 & 51 \\
\hline c9 & 15.991 & 0.440 & 31 & 18 & 46 \\
\hline c10 & 14.720 & 0.302 & 29 & 20 & 50 \\
\hline c11 & 17.409 & 0.477 & 34 & 17 & 42 \\
\hline $\mathrm{c} 12$ & 16.620 & 0.405 & 32 & 18 & 44 \\
\hline c13 & 14.850 & 0.304 & 29 & 20 & 49 \\
\hline c14 & 12.206 & 0.404 & 24 & 24 & 60 \\
\hline c15 & 12.994 & 0.451 & 25 & 23 & 57 \\
\hline c16 & 9.997 & 0.353 & 20 & 30 & 74 \\
\hline c17 & 9.006 & 0.301 & 18 & 33 & 82 \\
\hline c18 & 13.986 & 0.401 & 28 & 21 & 52 \\
\hline c19 & 13.709 & 0.335 & 27 & 21 & 54 \\
\hline $\mathrm{c} 20$ & 13.704 & 0.479 & 27 & 22 & 54 \\
\hline c21 & 13.200 & 0.392 & 26 & 22 & 56 \\
\hline $\mathrm{c} 22$ & 10.479 & 0.381 & 20 & 28 & 70 \\
\hline $\mathrm{c} 23$ & 13.316 & 0.467 & 26 & 22 & 55 \\
\hline c24 & 10.476 & 0.450 & 20 & 28 & 71 \\
\hline $\mathrm{c} 25$ & 16.751 & 0.487 & 33 & 18 & 44 \\
\hline c26 & 15.669 & 0.432 & 31 & 19 & 47 \\
\hline c27 & 13.657 & 0.436 & 27 & 22 & 54 \\
\hline $\mathrm{c} 28$ & 14.490 & 0.477 & 28 & 20 & 51 \\
\hline c29 & 10.743 & 0.488 & 21 & 28 & 69 \\
\hline c30 & 9.805 & 0.436 & 19 & 30 & 76 \\
\hline $\mathrm{c} 31$ & 14.501 & 0.408 & 28 & 20 & 51 \\
\hline $\mathrm{c} 32$ & 11.622 & 0.421 & 23 & 25 & 64 \\
\hline c33 & 11.912 & 0.441 & 23 & 25 & 62 \\
\hline c34 & 11.042 & 0.438 & 22 & 27 & 67 \\
\hline $\mathrm{c} 35$ & 10.377 & 0.412 & 20 & 28 & 71 \\
\hline
\end{tabular}



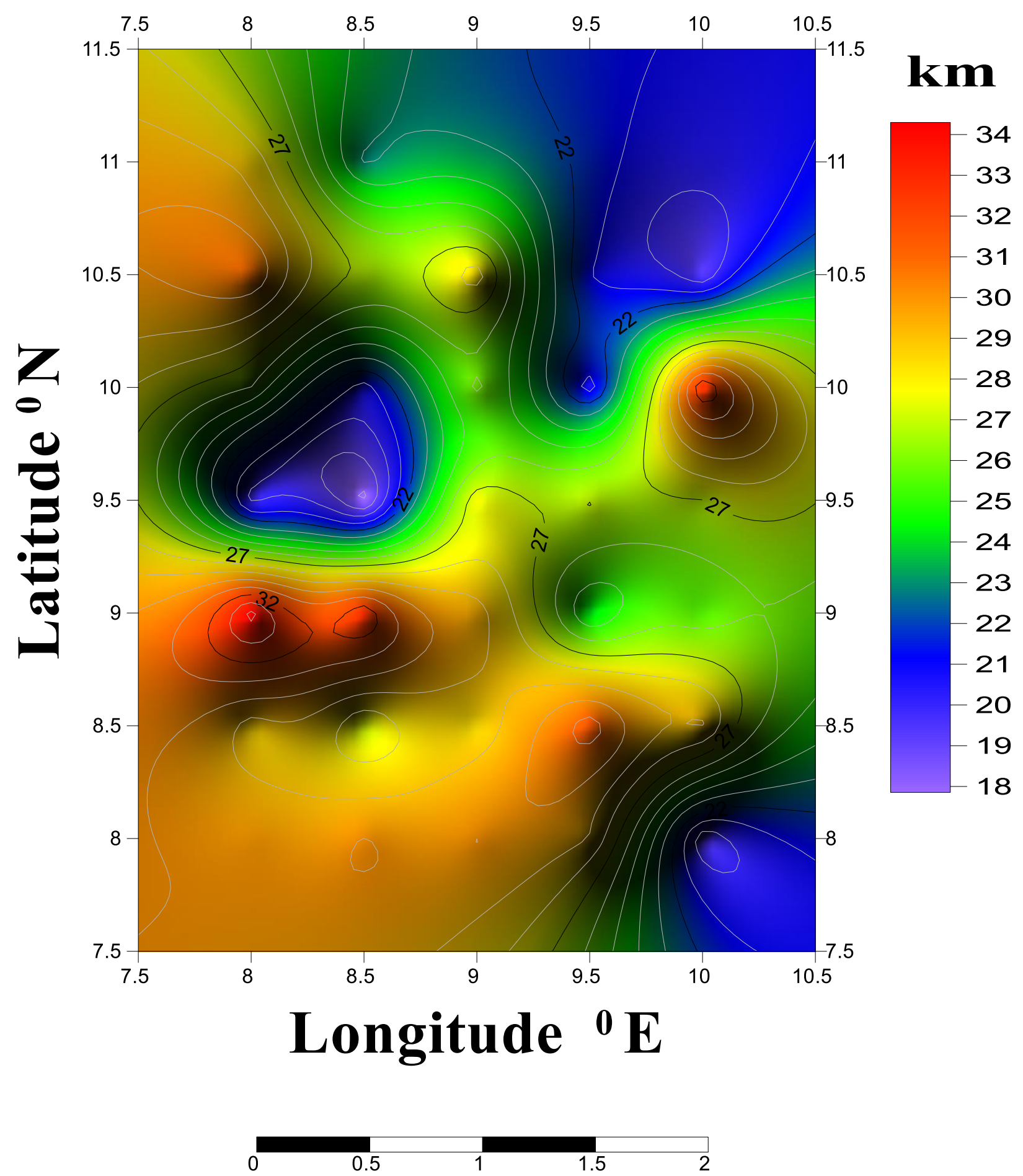

Fig.7: Curie point depth map of the study area using Surfer 8 software. 

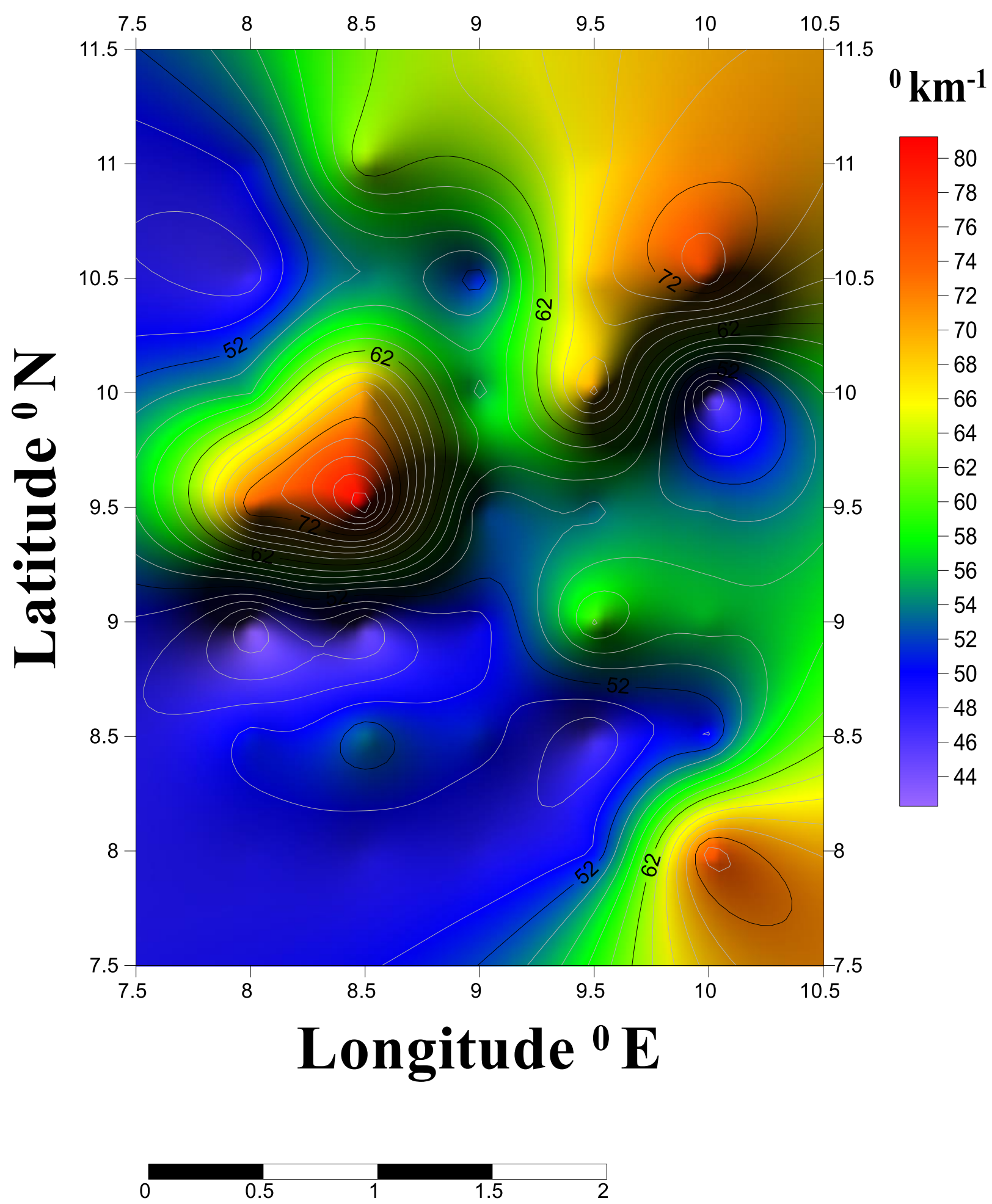

Fig.8: Geothermal gradient map of the study area using Surfer 8 software 

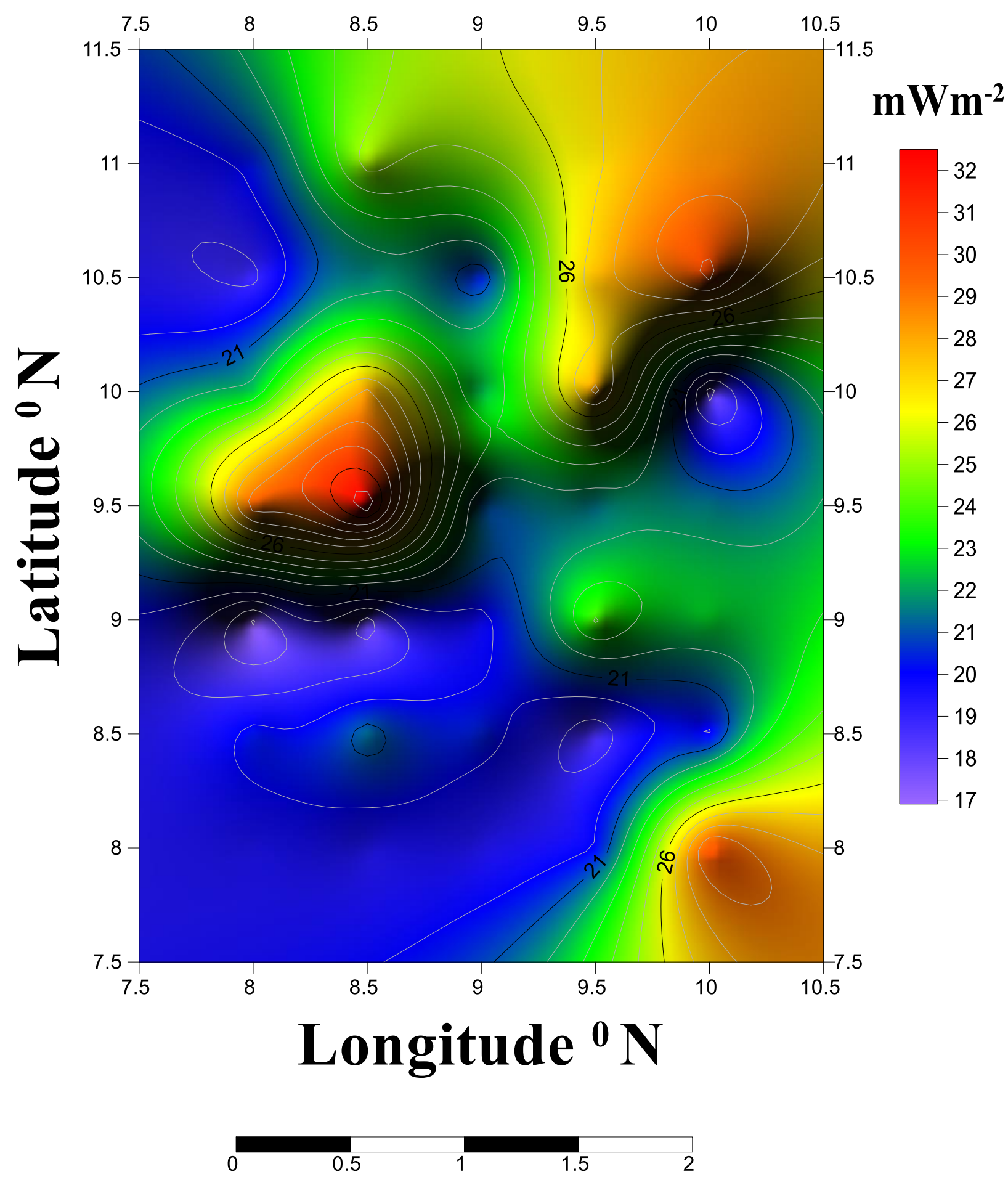

Fig.9: Heat flow map of the study area using Surfer 8 software. 


\section{Conclusion}

In this research, high resolution aeromagnetic data has been used to investigate the present of anomalies and the curie point depth of the study area. The quantitative (Spectral analysis) interpretation technique was chosen to achieve the outlined objectives of this research. From (Fig.7.) the curie point depths are deeper in the south, southwest, northwest, and northeast of the study area and shallower in the extreme northeast, southeast and part of the west. From Fig.8., the thermal gradient tends to be higher mainly in the north, central and extreme southeast of the study area and lower in most of the south, extreme southwest and extreme northwest. From Fig.9, the heat flow tends to be higher mainly in the north, central and extreme southeast of the study area and lower in most of the south, extreme southwest and extreme northwest. The above characteristics of these areas according to Stein and Stein (1994) and Tanaka et al., (1999), reveals that, they might probably be good sources for geothermal and thereby recommended for both geothermal exploration and exploitation. 


\section{Declarations}

\section{Availability of data and materials}

Not applicable

\section{Competing interests}

The authors declare that they have no competing interests.

\section{Funding}

Not applicable

\section{Authors' contributions}

George Idena ODIDI carried out the data acquisition and processing, participated in research analysis, drafting of the manuscript and interpretation of results. Abu MALLAM participated in supervision of processing, review of technical processing steps, assessment and analysis of results and approval of the version to be published. Naeem NASIR participated in review and analysis of results. All authors approved the final manuscript.

\section{Acknowledgments}

The authors would like to thank the department of Physics, University of Abuja, Nigeria for providing the convenient environment for this research to be carrying out and to all the anonymous reviewers for their contributions towards the improvement of this manuscript. 


\section{References}

Abdulsalam, N. N., Mallam, A. and Likkason, O. K. Evidence of some tectonic events in Koton Karifi area, Nigeria, from aeromagnetic studies. Journal of petroleum and gas exploration research. 2013; Vol. 3(1) pp. 7-15.

Abdullahi, M., Kumar, R. and Singh, K.U. Magnetic basement depth from high -resolution aeromagnetic data of parts of lower and middle Benue Trough (Nigeria) using scaling spectral method. Journal of African Earth Sciences. 2019; Volume 150, Pages 337-345. https://doi.org/10.1016/j.jafrearsci.2018.11.006.

Aboud, E., Salem, A. and Mekkawi, M. Curie depth map for Sinai Peninsula, Egypt deduced from the analysis of magnetic data. Tectonophysics. 2011; 506, 46-54.

Adelana, A. M.S., Olasehinde, I.P., Bale, B.R., Vrbka, P., Edet, E.A. and Goni, B.I. An overview of the geology and hydrogeology of Nigeria. DOI: 10.1201/9780203889497.ch11. Retrieved $31^{\text {st }}$ May, 2018.

Anakwuba, E., Okeke, H., Chinwuko, I. and Onyekwelu, C. Estimation of Curie isotherm and heat flow of eastern Chad basin, Nigeria from spectral analysis of aeromagnetic data. SEG, International Conference and Exhibition, Barcelona, Spain, 3-6 April 2016.

Bello, R., Ofoha, C. C. and Wehiuzo, N. Geothermal Gradient, Curie Point Depth and Heat Flow Determination of Some Parts of Lower Benue Trough and Anambra Basin, Nigeria, Using High Resolution Aeromagnetic Data. Physical Science International Journal. 2017; 15(2): 1-11.

Bhattacharrya, B.K. Continuous spectrum of the total magnetic field anomaly due to a rectangular prismatic body. Geophysics. 1966; 31, 97-121.

Bhattacharyya, B. and Leu, L.K. Analysis of magnetic anomalies over Yellowstone National Park. Mapping the Curie-point isotherm surface for geothermal reconnaissance.J. Geophys. Res. 1975; 80, 461-465.

Blakely, R. J. Curie temperature analysis and tectonic implications of aeromagnetic data from Nevada. J Geophys Res. 1988; 93(B10):11817-11832

Blakely, R.J. Potential Theory in Gravity and Magnetic Applications, Cambridge University Press, Cambridge, United Kingdom. 1995.

Blakely, R.J. and Hassanzadeh, S. Estimation of depth to magnetic source using maximum entropy power spectra with application to the Peru-Chile trench. Geol. Soc. Am. Mem. 1981; 154, 667-681.

Byerly, P.E.and Stolt, R.H. An attempt to define the Curie point isotherm in northern and central Arizona. Geophysics. 1977; 42, 1394-1400. 
Carter, J. D., Barber, W. and Tait, E.A. The geology of parts of Adamawa, Bauchi

and Bornu Provinces in north-eastern Nigeria. Bulletin of the Geological Survey Nigeria, 30. 1963.

Chiozzi, P., Matsushima, J., Okubo, Y., Pasquale, V. and Verdoya, M. Curie-point depth from spectral analysis of magnetic data in central-southern Europe. Phys. Earth Planet. Inter. 2005;152, 267-276.

Ekwueme, B. N. Structural Orientations and Precambrian deformation episodes of Uwet area, Oban massif. Precambrian Research. 1987; 34, 269-289.

Eletta B.E. and Udensi E.E. Investigation of the Curie Point Isotherm from the Magnetic Fields of Eastern Sector of Central Nigeria. Geosciences. 2012; 2(4): 101-106.

Eppelbaum, L.V. and Pilchin, A.N. Methodology of Curie discontinuity map development for regions with low thermal characteristics: An example of Israel. Earth and Planetary Science Letters. 2006; 243536 - 551.

Farnbauer, B. and Tietz, G. The individuality of laterites developed on the JosPlateau/Central- Nigeria (in Deutsch). Zbl. Geol. Palaeont. 2000; Tiel I, Heft 5/6, $509-525$.

Fourier, J. Analytical Theory of Heat. Dover Publications, New York. 1955.

Hinze, J. W., Von Frese, B.R.R. and Saad, H. A. Gravity and Magnetic Exploration 2013.

Principles, Practices, and Applications, Cambridge University Press, New York.

Igwesi, I. D. and Umego, N. M. Interpretation Of Aeromagnetic Anomalies Over Some Parts Of Lower Benue Trough Using Spectral Analysis Technique. International Journal of Scientific \& Technology Research. 2013; volume 2, issue 8, Pp. 153-165.

Ikumbur, E. B., Onwuemesi, A. G., Anakwuba, E. K., Chinwuko, A. I., Usman, A.O. and Okonkwo, C. C. Spectral Analysis of Aeromagnetic Data over Part of the Southern Bida basin,West-Central Nigeria. International Journal of Fundamental Physical Sciences. 2013; 3(2), 27-31.

Kasidi, S. and Nur, A. Curie depth isotherm deduced from spectral analysis of magnetic data over sarti and environs of North-Eastern Nigeria. Sch. J. Biotechnol. 2012; 1 (3), 49-56. 
Kasidi, S and Nur, A. Estimation of Curie Point Depth, Heat Flow and Geothermal Gradient Infered from Aeromagnetic Data over Jalingo and Environs North - Eastern Nigeria. International Journal of Science. Emerging Tech. 2013; Vol-6. No. 6.

Kogbe, C. A. Geology of Nigeria. Rock View (Nigeria) Limited. Jos, Nigeria. 1989.

Kurowska, E. and Schoeneich. K. Geothermal Exploration in Nigeria. Proceedings of World Geothermal Congress, 2010. Bali, Indonesia, 25-29 April 2010.

Manea, M. and Manea, C.V. Curie Point Depth Estimates and correlation with subduction in Mexico. Pure and Applied Geophysics. 2011; 168(8): 1489-1499.

Mohammed, A., Adewumi, T., Kazeem, A. S., Abdulwaheed, R., Adetona, A. A. and Usman, A. Assessment of geothermal potentials in some parts of upper Benue Trough northeast Nigeria using aeromagnetic data. Journal of Geoscience, Engineering, Environment, and Technology. 2019; [S.1.], Vol. 4, no. 1, p. 7-15.

NGSA. Nigeria Geological Survey Agency’s published geological map. 2010.

Nur, A., Ofoegbu, C.O. and Onuoha, K.M. Estimation of depth to the Curie point isotherm in the Upper Benue Trough, Nigeria. Jour. Mining and Geol. 1999;35(1): $53-60$.

Nwankwo,L.I, Olasehinde, P.I and Akoshile, C.O. Heat flow anomalies from the spectral analysis of Airborne Magnetic data of Nupe Basin, Nigeria. Asian Journal of Earth Sciences. 2011; Vol.1. No.1, pp. 1-6

Nwankwo, L. and Sunday, J. A. Regional Estimation of Curie-point depths and succeeding geothermal parameters from recently acquired high-resolution aeromagnetic data of the entire Bida Basin, North-central Nigeria. Geoth. Energ. Sci.,. 2017; 5, 1-9.

Obaje, N. G. Geology and Mineral Resources of Nigeria. Nasarawa State University Dept. Geology and Mining Keffi Nigeria. 2009;p.50.

Okubo, Y., Graf, R.J., Hansent, R.O., Ogawa, K. and Tsu, H. Curie point depths of the island of Kyushu and surrounding areas Japan. Geophysics. 1985; 53, 481-494.

Reyment, R. A. Aspects of the Geology of Nigeria. University of Ibadan Press, Nigeria. 1965; 145pp.

Salako, A.K. Depth to Basement Determination Using Source Parameter Imaging (SPI) of Aeromagnetic Data: An Application to Upper Benue Trough and Borno Basin, Northeast, Nigeria. Academic Research International. 2012; Vol. 5(3). 
Smith, R.B. and Braile, L.W. The Yellowstone Hotspot, 3. J. Volcanol. Geotherm.

Res. 1994; 61, 121-187.

Spector, A.and Grant, F.S. Statistical models for interpreting aeromagnetic data. Geophysics. 1970; 35, 293-302.

Stampolidis, A., Kane, I., Tsokas, G.N. and Tsourlos, P. Curie point depths of lbania inferred from ground total field magnetic data. Surv. Geophys.2005; 26, 461-480.

Stein, C.A. and Stein, S. Constraints on hydrothermal heat flux through the oceanic lithosphere from global heat flow. J. Geophys. Res. 1994; 99, 3081-3095.

Tanaka, A., Okubo, Y. and Matsubayashi, O. Curie point depth based on spectrum analysis of the magnetic anomaly data in East and Southeast Asia. Tectonophysics. 1999; 306, 461-470.

Trifonova, P., Zheler, Z., Petrova, T. and Bojadgieva K. Curie point depths of the Bulgarian territory inferred from geomagnetic observations and its correlation with regional thermal structure and seismicity. Tectonophysics. 2009; 473:362-374. 


\section{Figures}

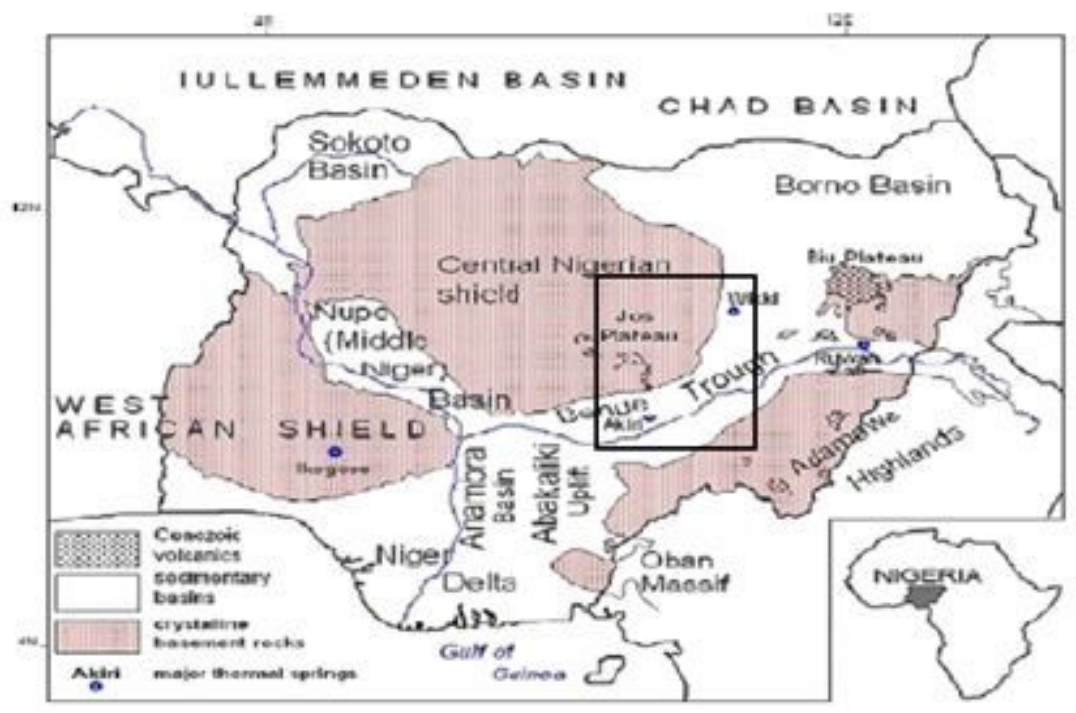

$\square$ Study Area

- Surface Geothermal manifestation-Hot.springs.

\section{Figure 1}

Geological setting and location of areas with major geothermal manifestation (Hot springs) in Nigeria (After Kurowska and Schoeneich, 2010).
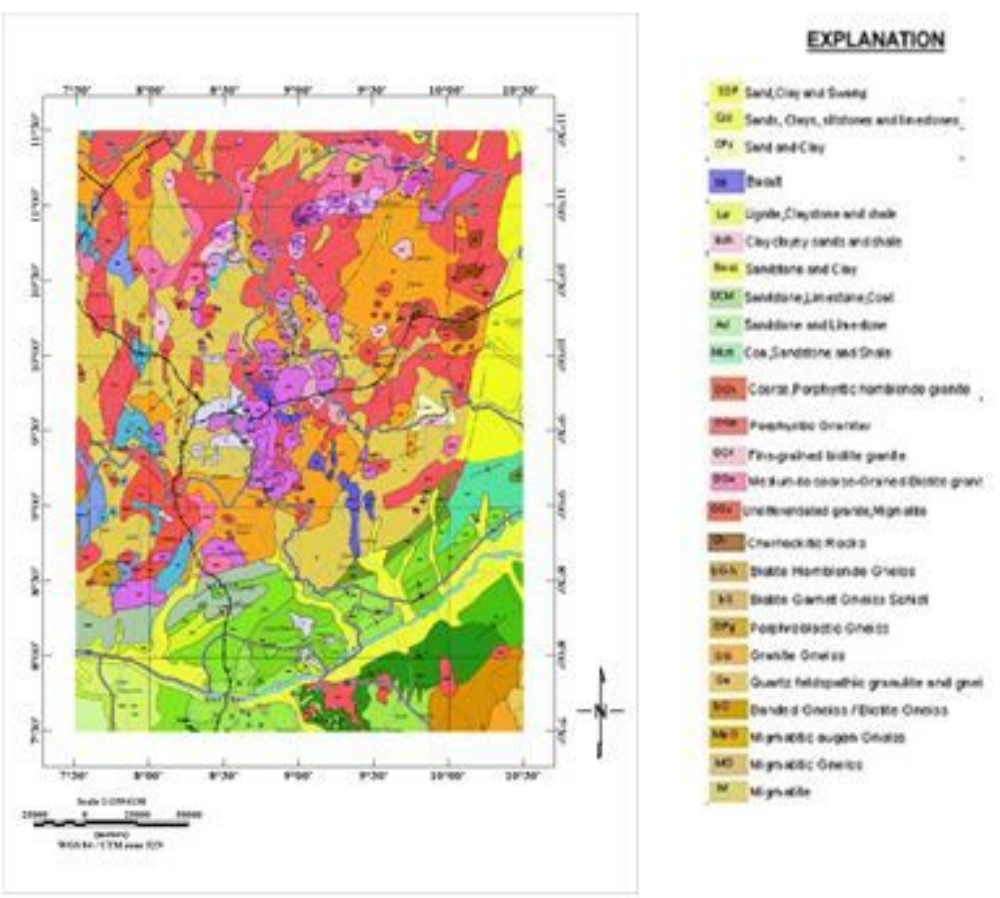

\section{Figure 2}

Geological Map of the study area (adapted after NGSA, 2010) 


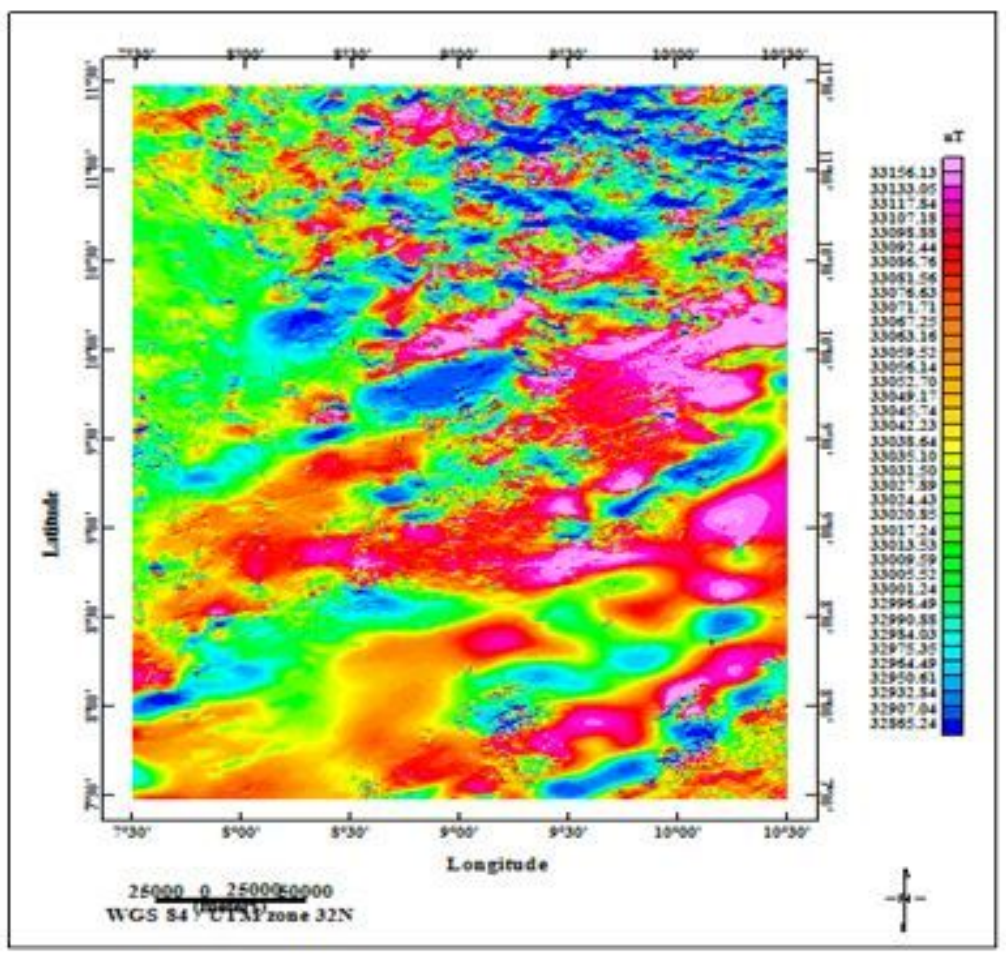

Figure 3

Total magnetic field intensity map of the study area.

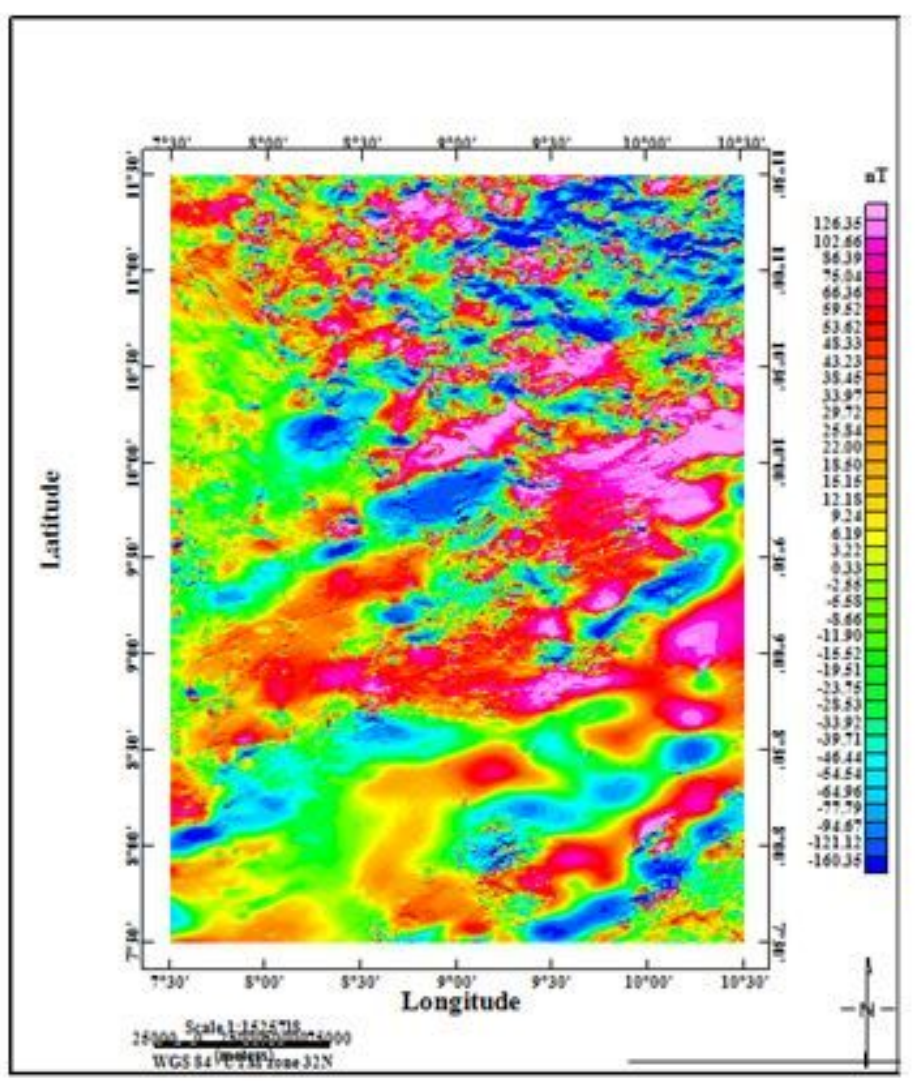

Figure 4 
Residual magnetic field intensity map of the study area.

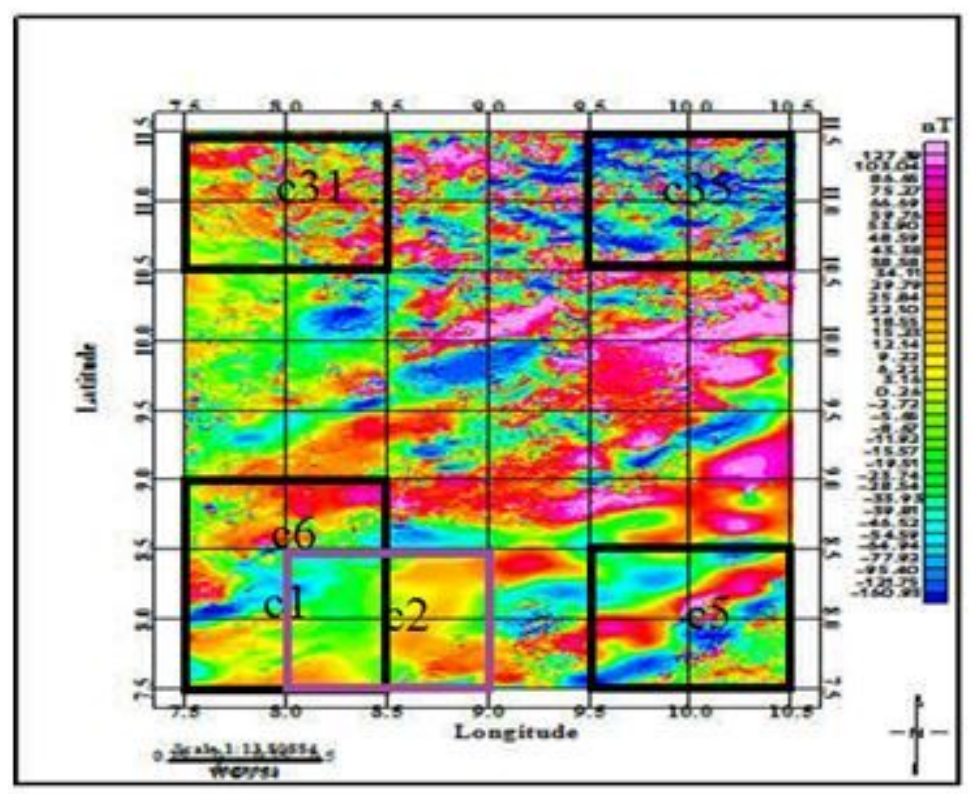

\section{Figure 5}

Residual magnetic field intensity divided into thirty-five square windows (110km by $110 \mathrm{~km}$ each) from c1 to $c 35$ at $50 \%$ overlapping. 

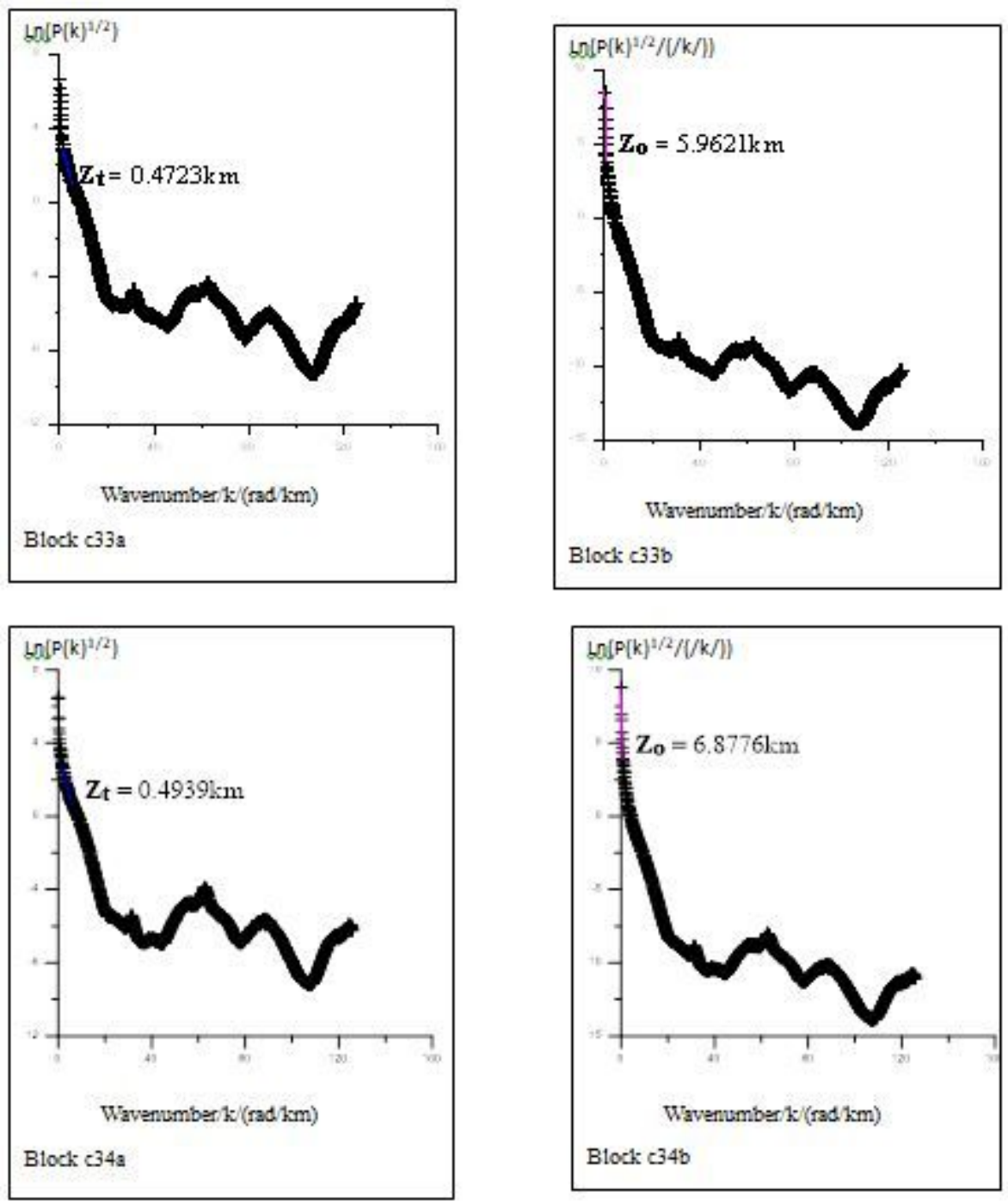

\section{Figure 6}

Graphs of the logarithms of the spectral energies for blocks c33, and c34, showing the determined values of Zo and Zt. using Grapher 8 software and the calculated Curie point depths are $11 \mathrm{~km}$ and $13 \mathrm{~km}$ respectively. 

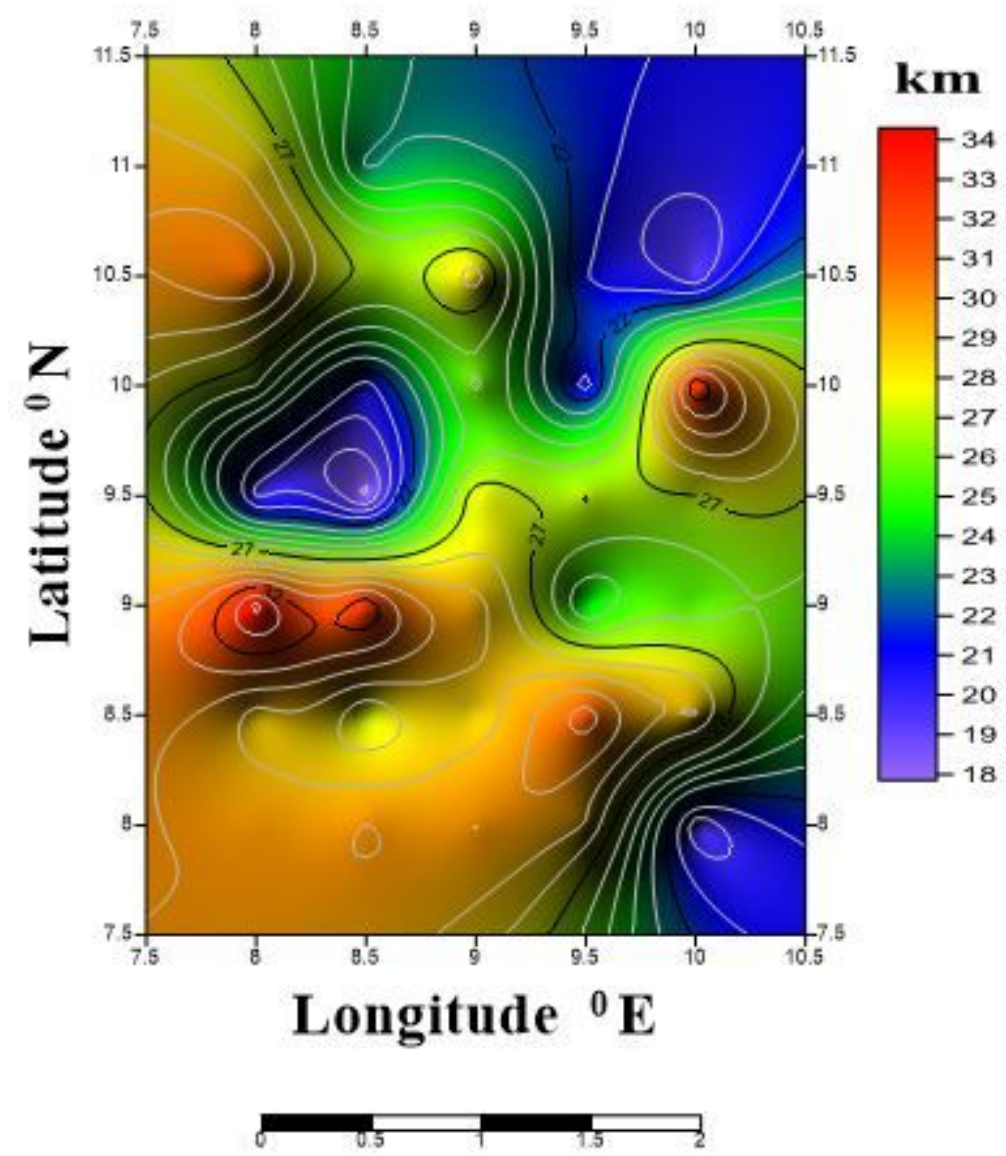

Figure 7

Curie point depth map of the study area using Surfer 8 software. 

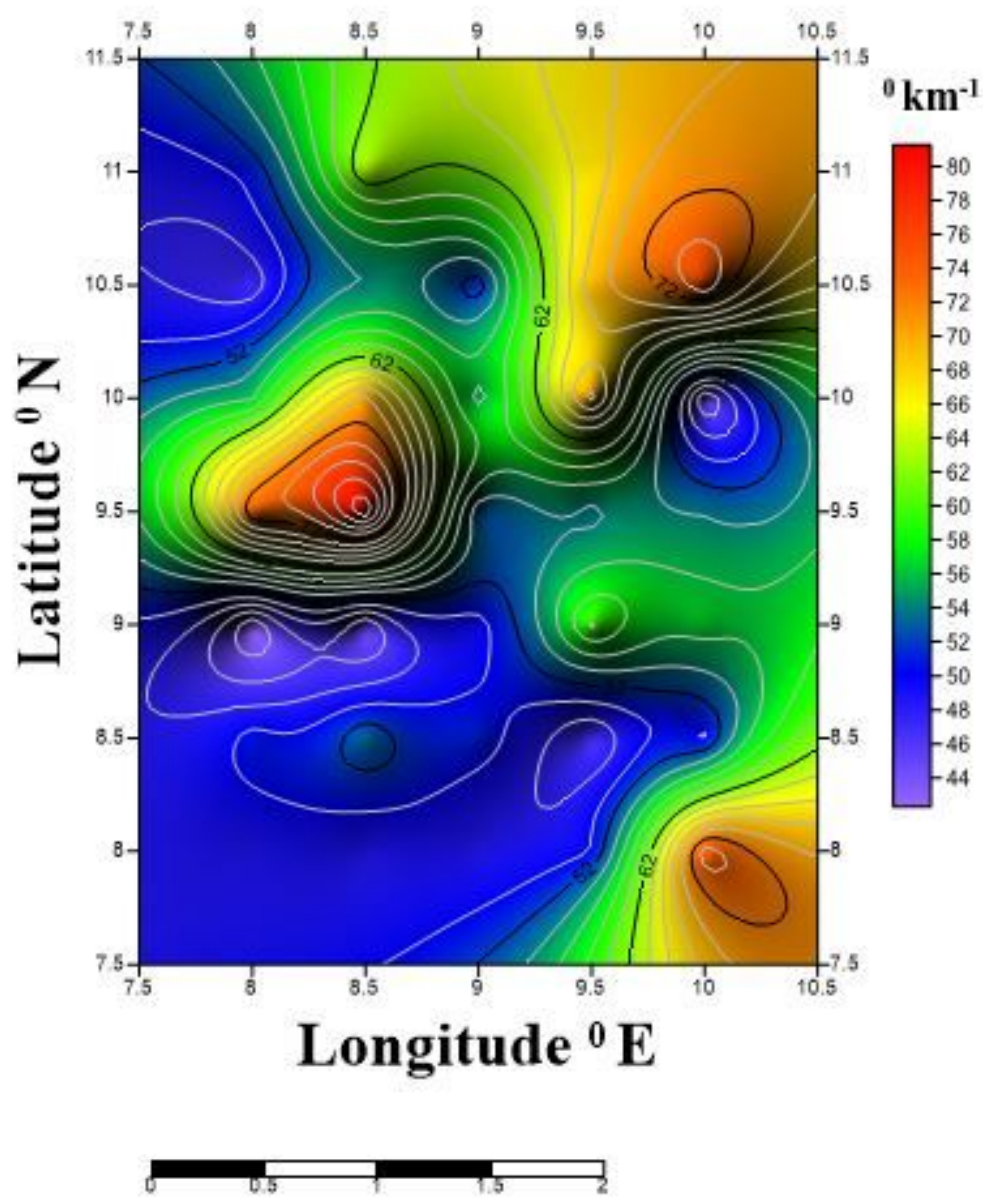

Figure 8

Geothermal gradient map of the study area using Surfer 8 software 


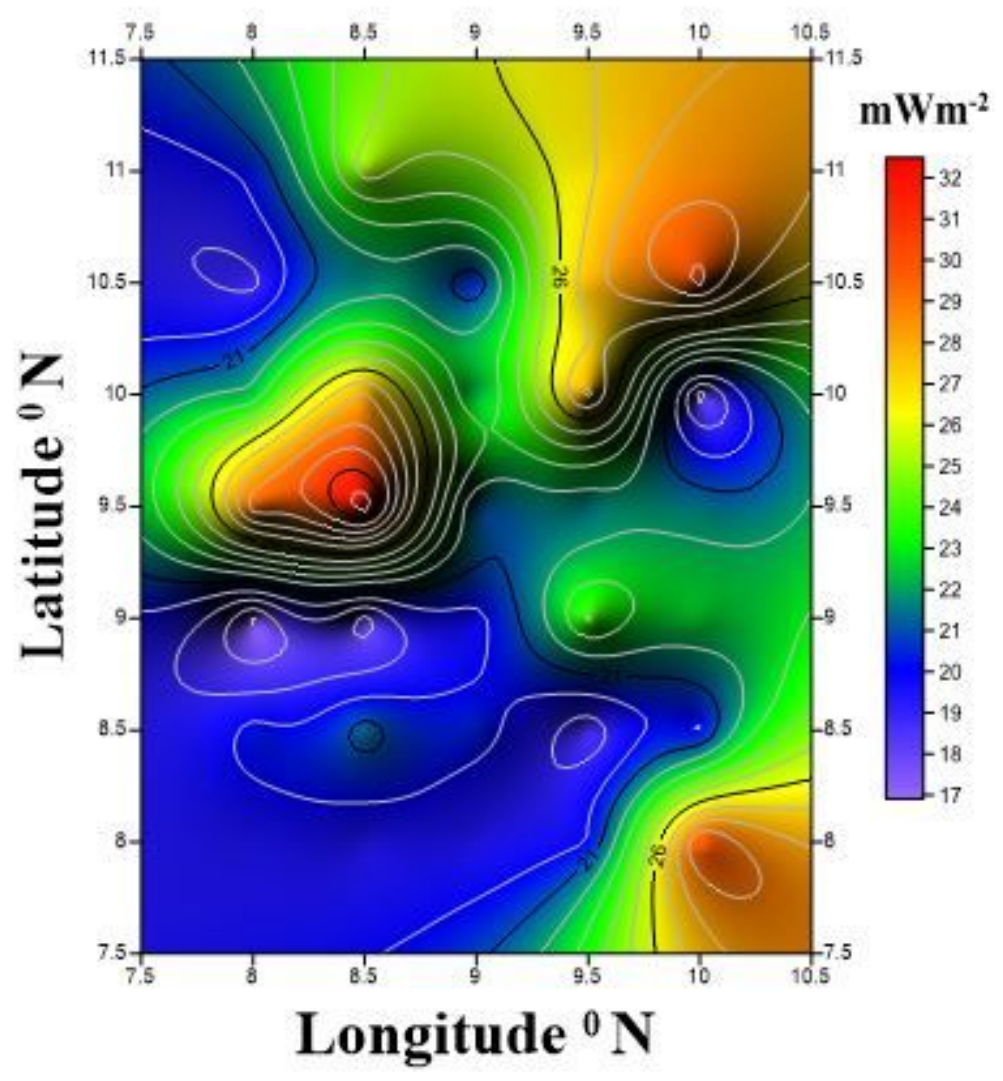

Figure 9

Heat flow map of the study area using Surfer 8 software. 